\title{
Diet quality of suckling calves and mature steers on Northern Great Plains rangelands
}

\author{
E. E. GRINGS, D. C. ADAMS, AND R. E. SHORT
}

Authors are with: USDA-ARS at Ft. Keogh Livestock and Range Research Laboratory, Rt. 1, Box 2021, Miles City, Mont. 59301 (Grings and Short) and the University of Nebraska-Lincoln West Central Research and Extension Center, Rt. 4. Box 46A, North Platte 69101 (Adams).

\begin{abstract}
A study was conducted over 2 years to evaluate the quality of forage selected by suckling calves compared to mature steers. Diets were collected from esophageally cannulated suckling calves or from steers that were two-years-old or older. Sampling was conducted in June, July, September, October, and November in each of 2 years. The forage portion of diets of esophageally fistulated suckling calres (beginning 115 to 136 days of age) were $21 \%$ greater $(P<0.01)$ in crude protein and 5\% less $(P<0.06)$ in neutral detersent fiber relative to those consumed by mature steers in June and July. Diets of calves also contained $14 \%$ less $(P<0.01)$ acid detergent fiber than diets of mature steers in June. There vere no differences in diet quality due to age during September, October, and November of either year. We conclude that suckling calves selected diets of higher quality than did mature steers early in the growing season. Forage quality may have allowed selective behavior at this time, low forage intakes of calves may have allowed mere time for selection, or exploratory grazing by calves may have resulted in diets with increased nutrient quality in early summer.
\end{abstract}

Key Words: beef cattle, nutrients, pasture

Determining the quality of diet consumed by free-ranging livestock is often accomplished through the use of esophageally cannulated animals. Despite extensive research on the diets of esophageally fistulated cattle, only limited information concerning diets of suckling calves has been published. Studies with suckling calves and cows show variable, but different, quality of diets selected by the calf and cow (Horn et al. 1979, Peischel 1980, Ansotegui 1986). Our objective was to determine differences in quality of diet selected by suckling calves and mature cattle at varying ages. This would aid in evaluating weight

Contribution No. J-2918 from Montana Agr. Exp. Station. Mention of a proprietary product does not constitute a guarantee or warranty of the product by USDA, Montana Agric. Exp. Sta., or the authors and does not imply its approval to the exclusion of cther products that may also be suitable. USDA, Agricultural Research Serice, Northem Phains Area, is an equal opportunity/afímative action employer and all agency services are available without discrimination.

Mianuscript accepted 22 Nov. 1994. change patterns in these cattle throughout the year. Our hypothesis was that suckling calves would select diets of higher quality than mature cattle and that this effect is dependent upon season.

\section{Materials and Methods}

A 2-year study (1989 and 1990) was conducted at the Fort Keogh Livestock and Range Research Laboratory near Miles City, Mont. ( $46^{\circ} 22^{\prime} \mathrm{N} 105^{\circ} 5^{\prime} \mathrm{W}$ ). Average rainfall in the area is $338 \mathrm{~mm}$ with $60 \%$ received during the 150 day, mid-April to mid-September growing season (Fig. 1).

Each year esophageal-fistulae were established in suckling beef calves at an average of 34 days of age (average body weight $=65$ $\mathrm{kg}$ ) with the procedure described by Adams et al. (1991). Esophageal extrusa was collected on 15 June (average calf age = 115 days), 26 July, 20 September, 24 October, and 29 November 1989 from 6 suckling calves and five 5-year-old esophageally-fistulated steers (average weight $=825 \mathrm{~kg}$ ) and on 6 June (average calf age $=136$ days), 20 July, 13 September, 26 October, and 28 November 1990 from 6 suckling calves, five 2-year-old steers and five 6-year-old steers. The mature steers and calves with their dams were penned with water but not given access to feed at 1600 hour the day before collections were made. Collections were made the following morning at 0700 hour by allowing both age groups to graze in the same area for 20 to 30 minutes.

June collections were made on 68 ha of rangeland that had been plowed and seeded to Russian wildrye [Psathrostachys juncea (Fibch.) Nevski]. Other important forage species in this pasture included western wheatgrass [Pascopyrum smithii (Rydb.) Love], cheatgrass [Bromus tectorum L.], and Japanese brome [Bromus japonicus Thunb.]. July collections were made on 80 ha of native rangeland that was contour furrowed with a lister type plow and seeded with 'Ladak' alfalfa [Medicago sativa] as described by Kartchner et al. (1983). September, October, and November collections were made in pastures of native rangeland $(265,73$, and $73 \mathrm{ha}$, respectively). Major forage species in the contour furrowed and native rangeland pastures were western wheatgrass, blue grama [Bouteloua gracilis (H.B.K.) Lag ex Griffiths], needle-and-thread grass [Stipa comata Trin. and Rupr.], buffalo grass [Buchloe dactyloides (Nutt.) Engelm.], threadleaf sedge [Carex filifolia Nutt.] cheatgrass, Japanese brome, and various forbs. 


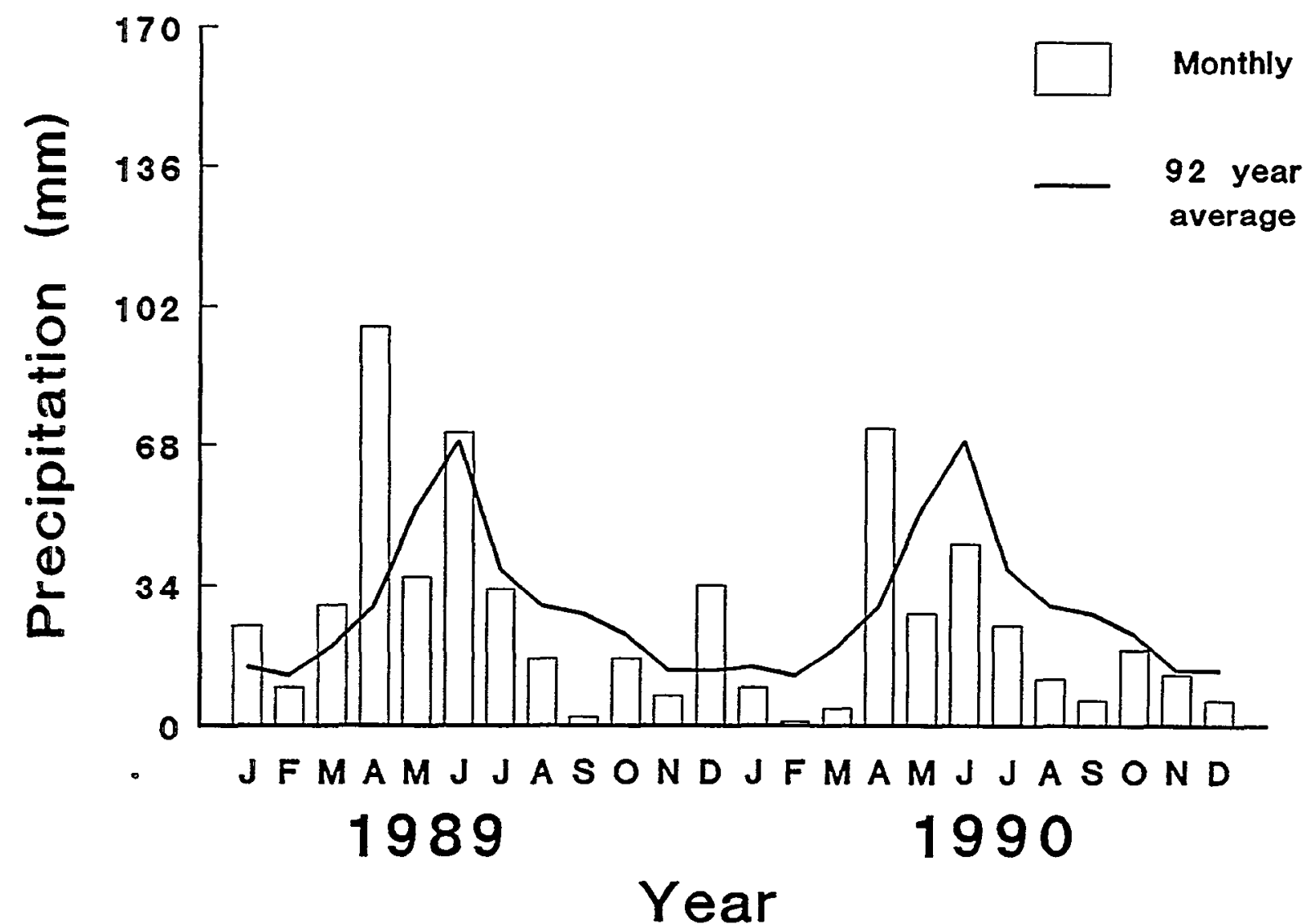

Fig. 1. Precipitation during the study years 1989 and 1990 compared to a 92 year average.

Fistula extrusa was dried at $45^{\circ} \mathrm{C}$ and ground through a $1 \mathrm{~mm}$ screen in a Wiley mill. Fistula extrusa samples were analyzed for crude protein, organic matter by AOAC (1984), and for neutral detergent fiber, acid detergent fiber, and acid detergent lignin by Goering and Van Soest (1970).

Statistical analysis was conducted using the general linear models procedure of SAS (1985). Chemical composition of esophageal masticate did not differ $(P>0.10)$ between 2-year-old and 6-year-old steers in 1990. Therefore, both 2- and 6-year old steers were considered "mature" age class animals. The final analysis for both years then contained 2 age classes: calf and mature. The final statistical model used to compare diets of suckling calves with diets of mature steers was a split-plot design with age class, year, and age class $x$ year in the whole plot and were tested using the animal within age class $x$ year mean square as the error term. Sampling date, sampling date $x$ year, sampling date $x$ age class, and sampling date $x$ age class $x$ year were included in the subplot analysis. Subplot components were tested using the residual mean square as the error term. When a significant $(P<0.05)$ F-test was observed, differences among means were tested using least significant difference procedures.

\section{Results}

Concentrations of all nutrients in esophageal extrusa were influenced by animal age and month of sampling (Table 1 and
Fig. 2). Year of sampling affected $(P<0.01)$ concentrations of crude protein and acid detergent fiber but not neutral detergent fiber or acid detergent lignin. However, there were animal age $x$ year $(P<0.01)$ and month $\times$ year $(P<0.05)$ interactions for acid detergent lignin, a month $\times$ animal age interaction $(P<0.01)$ for crude protein and a month $\times$ year interaction $(P<0.01)$ for neutral detergent fiber. A 3-way interaction among animal age, month, and year also existed $(P<0.01)$ for neutral detergent fiber.

Crude protein was greater $(P<0.01)$ in diets selected by calves than mature steers in June and July, but not in other months. Concentrations of neutral detergent fiber in diets of grazing cattle varied with combinations of age class, year, and month. Calves selected diets with less $(P<0.05)$ neutral detergent fiber than mature steers in June 1989, July 1989, July 1990, and November 1990. In June, steers selected diets containing similar amounts of neutral detergent fiber in both years. Calves selected diets with greater $(P<0.01)$ neutral detergent fiber concentrations in June 1990 than 1989 so that dietary neutral detergent fiber for calves and steers did not differ in June 1990. Both age classes selected diets with less $(P<0.01)$ neutral detergent fiber in July 1990 than July 1989. Steers also selected diets containing less $(P=0.05)$ neutral detergent fiber in Sept of 1990 than 1989. Calves and steers collected diets similar in neutral detergent fiber in 1989, but in 1990 calf diets contained less $(P=0.05)$ neutral detergent fiber than steer diets.

Diets of suckling calves contained less $(P<0.05)$ acid deter- 
Table 1. Model components, degrees of freedom (df), and mean squares for chernical composition of esophageal extrusa collected by steers and sucking calves.

\begin{tabular}{|c|c|c|c|c|c|}
\hline \multirow[t]{2}{*}{ Component } & \multirow[t]{2}{*}{$\mathrm{df}$} & \multicolumn{4}{|c|}{ Mean square } \\
\hline & & $\mathrm{CP}^{1}$ & NDF & $A D F$ & $\mathrm{ADL}$ \\
\hline Animal age & 1 & $58.63=$ & $132.92 *$ & $126.55^{*}$ & $11.33^{*}$ \\
\hline Year & 1 & $6+.27 \div$ & 32.06 & $234.75^{\approx}$ & 7.02 \\
\hline Animal age $\times$ Year & 1 & 5.15 & 5.07 & 47.01 & $20.49 \neq \cdots$ \\
\hline $\begin{array}{l}\text { Animal(Animal } \\
\text { age } \times \text { Year) }\end{array}$ & & & & & \\
\hline [Whole plot error] & 24 & 3.84 & $20.56 *$ & 20.39 & 2.78 \\
\hline Month & 4 & $127.04 \div$ & $129.51 *$ & $190.73=$ & $15.21 \neq *$ \\
\hline Month $\times$ Animal age & 4 & $10.01 *$ & 12.99 & 26.23 & 2.29 \\
\hline MonthXYear & 4 & 8.38 & $84.76^{*}$ & 27.65 & $12.36 \%$ \\
\hline $\begin{array}{l}\text { Arimal age X } \\
\text { Month X Year }\end{array}$ & 4 & 2.71 & $74.33 \div$ & 24.94 & 3.99 \\
\hline Subplot error & & 3.99 & 11.29 & 25.92 & 4.29 \\
\hline Subplot error df & & 66 & 63 & 65 & 65 \\
\hline
\end{tabular}

* Significant at the $\$ r$ and $1 \%$ levels of probability, respectively.

${ }^{\prime} \mathrm{CP}=$ crule protein: $\mathrm{ADF}=$ acid detergent fiber, $\mathrm{NDF}=$ neutral detergent

fiber, ADL = acid detersent lignin.

gent fiber than did diets of steers. Concentrations of acid detergent fiber in diets were less $(P<0.01)$ in 1990 than in 1989, and acid detergent fiber increased in diets throughout the grazing season. Fiber concentrations in available forage tend to increase as plants mature (Cogswell and Kamstra, 1976) and increases in dietary acid detergent fiber throughout the grazing season are reflective of changes in herbage chemical composition.

Calves selected diets containing less $(P<0.01)$ acid detergent lignin than steers in 1990, but not in 1989. Diets contained more $(P=0.05)$ acid detergent lignin in June 1990 than June 1989, and less $(P<0.01)$ in November 1990 than November 1989. Differences in acid detergent fiber and acid detergent lignin concentrations between diets of calves and mature steers indicates that diets of higher potential digestibility were being consumed by calves (Reid et al. 1988).

Diets selected in 1990 were generally of higher quality than those selected in 1989. This did not appear to be related directly to the amount of precipitation received during the growing season of each year as precipitation was greater in 1989 than 1990 (Fig. 1). Low precipitation in 1988 ( $40 \%$ of normal) may have influenced forage quality and, hence, diet quality in 1989.

\section{Discussion and Conclusions}

We concluded that suckling calves selected diets of higher quality than did mature steers early in the summer when calves were receiving much of their nutrient intake from milk, but not at later times. This differential effect may be caused by learning behavior, changes in forage quality, or increased forage intake by calves. The lack of differences between animal ages or between years during October and November may be related to the lack of opportunity to select a higher quality diet when available herbage is of poor quality. Data from our laboratory indicates that although cartle of different age classes may continue to select different plant species and plant parts throughout the year, this does not necessarily correspond to differences in chemical composition of the diet (Grings et al. 1994). Hodgson and Jamieson

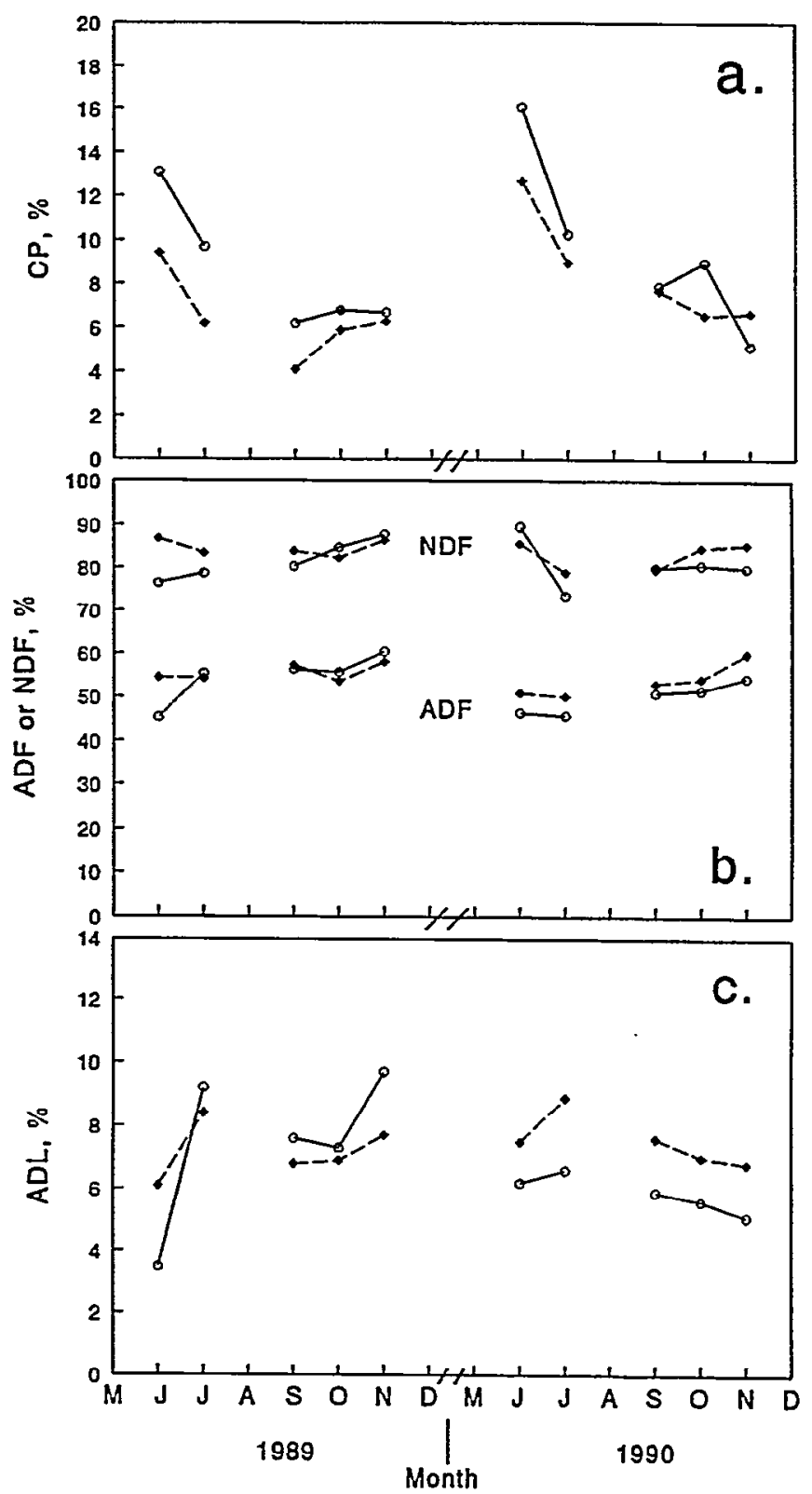

Fig. 2. Least squares means for a.) crude protein (CP); b.) neutral detergent (NDF) and acid detergent fiber (ADF); and c.) acid detergent lignin (ADL) expressed on an organic matter basis in the diets of steers (broken line) and suckling calves (solid line). Diets were collected during June, July, September, October, and November in 1989 and 1990 . Pooled standard error of the means were 2.0 for CP, 3.4 for NDF, 5.1 for ADF, and 2.1 for ADL.

(1981) found that 9-month old calves selected diets with greater digestibility than did nonlactating pregnant cows when both were grazing a pasture of perennial ryegrass, indicating that calves of this age do still possess the ability to select a diet of higher quality than mature cattle. Hodgson and Jamieson (1981) also found that 4-month old weaned calves spent more time grazing than cows but had fewer grazing bites per day and slower biting rates. Calves may have more time to be selective in their foraging due to the consumption of milk, a high quality food. As milk intake declines, forage consumption increases (Ansotegui 1986) and the 
calf may have less time available for diet selectivity. Forage consumption by steer calves grazing these pastures during the summer of the 2 years averaged $.5 \mathrm{~kg} \mathrm{day}^{-1}$ in June, $1.4 \mathrm{~kg}^{-1} \mathrm{day}^{-1}$ in July, and $2.3 \mathrm{~kg} \mathrm{day}^{-1}$ in September (unpublished data). An additional factor may be the amount of grazing experience of the different age class cattle. Steers were familiar with the pastures and did little exploratory grazing, while calves appeared more hesitant in their choice of food.

Other research has also shown that calves select diets with greater concentrations of crude protein (Horn et al. 1979, Peischel 1980, Ansotegui 1986) and less acid detergent fiber (Hom et al. 1979) than do miture animals. In contrast to our data, Peischel (1980) and Ansotegui (1986) found that young calves consumed diets with more neutral detergent fiber than did mature animals. However, Ansotegui (1986) found that by 125 days of age calves were selecting diets of similar neutral detergent fiber content to diets of mature animals. This is an age more similar to the calves used in this study.

Two possible explanations for differences in diet selection between calves and mature steers are: 1) selection of different plant species and 2) selection of different plant parts. Different plant species vary in protein concentration (Valentine 1990) and leaves contain more protein than stems (Brickoff et al. 1972, Poppi et al. 1980). Research on botanical composition of diets of different age animals would elucidate this mechanism and may provide information on the management implications of this difference in diet selection.

On similar range at this laboratory, suckling calves gained weight at a relatively constant rate from April through September, even though forage maturity advanced and milk consumption by the calf declined as season advanced (Adams et al. 1989). In contrast to the calves, their dams lost weight and body condition as the season advanced (Adams et al. 1989, 1993). Moreover, on this range yearling cattle had small or negative live weight gains by early August (Currie et al. 1989). Thus the combination of a small amount of milk and a higher quality forage diet selected by suckling calves than mature animals may explain in pan differences in live weight gain that occur between mature animals and suckling calves grazing summer range.

\section{Literature Cited}

Adams, D.C., R.E. Short, J.A. Pfister, K.R. Peterson, and D.V. Hudson. 1991. Surgical establishment of esophageal fistulae in suckling calves. J. Range Manage. 46:628-629.

Adsms, D.C., R.B. Staigmiller, and B.W. Knapp. 1989. Beef production from native and seeded Northern Great Plains ranges. J. Range Manage. $42: 243-247$.

Adams, D.C., R.B. Staigmiller, B.W. Knapp, and J.B. Lamb. 1993. Native or seeded rangeland for cows with high or low milk production. J. Range Manage. 46:474-478.

AOAC 19S4. Official Methods of Analy sis (14th Ed.). Association of Official Analytical Chemists. Washington, D.C.

Ansotegui, R.P. 1985. Chemical composition and rumen digesta kinetics of diets selected and influence of milk intake on forage intake by suckling calves grazing native range. Ph.D. Thesis, New Mexico State Univ. Las Cruces, N. M.

Erickorf, E.M., G.O. Kuhler, and D. Smith. 1972. Chemical composition of herbage, p. 247. In: Alfalfa Science and Technology (Ed. C. H. Hansun). Amer. Soc. Agron. Monogr. 15.

Cogswell, C. and L.D. Kamstra. 1976. The stage of maturity and its effect upon chemical composition of four native range species. J.
Range Manage. 29:460-463.

Currie, P.O., J.D. Volesky, D.C. Adams, and B.W. Knapp. 1989. Growth patterns of yearling steers determined from daily live weights. J. Range Manage. 42:393-396.

Goering, H.K. and P.J. Van Soest. 1970. Forage fiber analysis. ARS, USDA Agr. Handb. 379.

Grings, E.E., B.S. Hould, and R.E. Short. 1994. Diets of suckling calves and yearling steers on Northern Great Plains rangelands. p. 20 In: Abstr. Soc. Range Manage. Annu. Mtg. p. 20. (Abstr.)

Hodgson, J. and W.S. Jamieson. 1981. Variations in herbage mass and digestibility, and the grazing behaviour and herbage intake of adult cattle and weaned calves. Grass and Forage Sci. 36:39-48.

Horn, F.P., J.P. Telford, J.E. McCroskey, D.F. Stephens, J.V. Whiteman, and R. Totusek. 1979. Relationship of animal performance and dry matter intake to chemical constituents of grazed forage. J. Anim. Sci. 49: 1051-1058.

Kartchner, R.J., J.R. Wight, J.L. Bishop, and R.A. Bellows. 1983. Beef and forage production on contour furrowed rangeland interseeded with alfalfa. J. Range Manage. 36:479-482.

Peischel, H.A. 1980. Factors affecting milk and grass consumption of calves grazing native range. $\mathrm{Ph} . \mathrm{D}$. Thesis, Kansas State Univ. Manhattan, Kan.

Poppi, D.P., D.J. Minson, and J.H. Ternouth. 1980. Studies of cattle and sheep eating leaf and stem fractions of grasses. In: The voluntary intake, digestibility and retention time in the reticulo-rumen. Aust. J. Agr. Res. 32:99.

Reid, R.L., G.A. Jung, and W.V. Thayne. 1988. Relationships between nutritive quality and fiber components of cool season and warm season forages: A retrospective study. J. Anim. Sci. 66:1275-1291.

SAS. 1985. SAS user's guide: Basics. SAS Institute, Cary, N.C.

Valentine, J.F. 1990. Grazing Management. Academic Press, Inc. San Diego, Calif. 